\title{
Micronutrient Dynamics on Addition of a Rapid Organic Fertilizer Produced from Degradable Waste in Banana
}

\author{
Naveen Leno* and C.R. Sudharmaidevi
}

Kerala Agricultural University, College of Agriculture, Trivandrum 695 522, Kerala, India

*Corresponding author

\begin{abstract}
A B S T R A C T
\section{Keywords}

Thermochemical processing, Solid waste, Organic fertilizer,

Micronutrient availability, Foliar concentration, Bunch weight, Banana, Total dry matter

Article Info

Accepted:

10 December 2017

Available Online:

10 January 2018

A field experimental study was conducted to assess the impact of the rapid organic fertilizer produced by thermochemical processing of degradable household waste in the dynamics of plant available essential micronutrients in banana (Musa spp. variety Nendran). The experiment was laid out in Randomised Block Design with 8 treatments and 3 replications. Soil test based micronutrients, both as soil application and as foliar spray were compared in treatment combinations involving farmyard manure as well as rapid organic fertilizer. The organic fertilizer produced by rapid thermochemical processing was capable of a steady supply of plant available micronutrients in soil over the conventional farmyard manure based fertilizers. The resultant foliar micronutrient concentration from both sources of organic fertilizers did not exhibit significant variation. Direct foliar application of micronutrients was not advantageous over soil application in conjunction with other nutrients, irrespective of the organic manure source, thus reducing the cost of production. Application of rapid organic fertilizer fortified with soil test based micronutrients favoured crop productivity in banana with enhanced total dry matter production and on par bunch yield with farmyard manure. The rapid organic fertilizer produced from degradable solid waste through thermochemical processing could be considered an effective substitute for farmyard manure.
\end{abstract}

\section{Introduction}

Thermochemical processing technology has been propounded to be a rapid method of decomposition of degradable solid waste to organic fertilizer (Sudharmaidevi et al., 2017). The fertility status of the organic fertilizer produced by this method has been assessed and is found to be conforming to city compost which is suitable for application to crops and is non-toxic to the environment (Leno et al., 2016). All organic manures improve the behaviour of several elements in soils through their active groups such as fulvic and humic acids which have an ability to retain elements over a period of time and are broken down slowly by microorganisms (Fawsy et al., 2106). Organic manures, irrespective of the source from which it is formed, are considered to be preferential in supplying various micronutrients like $\mathrm{Fe}, \mathrm{S}, \mathrm{Mo}, \mathrm{Zn}$ and $\mathrm{Cu}$ along with other major nutrients to soil. This is in addition to improving the soil physical and chemical properties of soil such as 
aggregation, aeration, permeability, water holding capacity which would nurture soil health and soil quality leading to sustainable agriculture (Lyngdoh et al., 2017). Micronutrients play a crucial role in plant metabolism which ultimately reflects not only on the growth and development of crop plants but also on crop yield. Zinc is vital in plant metabolic processes like cell wall development, respiration, photosynthesis and enzyme activity (Das, 2003). Iron is a component of ferrodoxins, active in photosynthesis, nitrate and sulphate reduction processes and nitrogen assimilation (Marschner, 1995). Micronutrients are also known to have a decisive role in the mineral nutrition of banana, a fruit crop of 10 month duration. Mohapatra et al., (2010) on a study of the banana pulp composition found a mean content $0.75 \mathrm{mg} \mathrm{Fe}, 0.67 \mathrm{mg} \mathrm{Mn}, 0.39 \mathrm{mg}$ $\mathrm{Zn}, 0.26 \mathrm{mg} \mathrm{Cu}$ and $0.16 \mathrm{mg} \mathrm{B}$ per $100 \mathrm{~g}$ of fruit pulp in AAB variety banana. The present study was conducted to assess the impact of the rapid organic fertilizer produced by thermochemical processing of degradable household waste in the dynamics of plant available essential micronutrients in banana.

\section{Materials and Methods}

\section{Experimental site}

A field experiment on banana (Musa spp. variety Nendran) was laid out in Randomised Block Design with 8 treatments (Table 1) and 3 replications. The experiment was conducted from October 2014 to August 2015 at the College of Agriculture, Trivandrum, Kerala, India. The soil in the experimental site was clayey, kaolinitic, isohyperthermic, Typic Kandiustults. The soil was moderately acidic, with a high status of organic carbon content $(1.69 \pm 0.3 \%)$, available $\mathrm{P}(180 \pm 23), \mathrm{K}(358 \pm$ 26) and medium to high in $N(539 \pm 13)$. Among the secondary nutrients, $\mathrm{Mg}$ alone was deficient $\left(78.6 \pm 4.4 \mathrm{mgkg}^{-1}\right)$. With a content of
$0.08 \pm 0.01 \mathrm{mgkg}^{-1}, \quad \mathrm{~B}$ was the sole micronutrient element that exhibited deficiency.

\section{Soil and plant analysis}

For soil analysis, samples from $0-15 \mathrm{~cm}$ depth were collected prior to the start of the experiment, then at 4 months (active growth stage) and at harvest. Determination of $\mathrm{pH}$ was done in a 1:2.5 (w/v) soil/water extract using $\mathrm{pH}$ meter, available $\mathrm{N}$ by distillation Bray No1. extractable $\mathrm{P}$ by spectro photometry, available (neutral $1 \mathrm{~N}$ ammonium acetate extractable) $\mathrm{Ca}, \mathrm{Mg}, \mathrm{K}$ and $0.1 \mathrm{~N} \mathrm{HCl}$ extractable $\mathrm{Fe}, \mathrm{Mn}, \mathrm{Zn}$ and $\mathrm{Cu}$ by atomic absorption spectrophotometry (A Analyst 400, PerkinElmer Inc., USA) and $\mathrm{B}$ by spectrophotometry (Azomethine-H method). For plant analysis, index leaf parts were collected at 6 months to find out the foliar concentration. Samples were dried in an oven at $65^{\circ} \mathrm{C}$ and $0.2 \mathrm{~g}$ sample was digested using nitric-perchloric (9:4) acids and estimation of individual elements was carried out. For determination of $\mathrm{B}$, dry ashing and extraction with $0.36 \mathrm{~N} \mathrm{H}_{2} \mathrm{SO}_{4}$ was followed.

\section{Observations on yield characters}

The fresh weight of pseudostem, leaves, fruits and rhizome were recorded at harvest. Samples of these parts were separately oven dried at $65^{\circ} \mathrm{C}$ till they attained constant weight to find out the dry weight. Total dry weight was computed and expressed in $\mathrm{kg} \mathrm{ha}^{-1}$.

\section{Statistical analysis}

The data on the field experiment were analysed statistically by applying the techniques of analysis of variance. The $\mathrm{F}$ values for treatments were compared with the table values. If the effects were significant, critical differences at the 5\% significance level were calculated for effecting comparison 
among the means. Data analytical package Web Agri Stat Package (WASP) ver.2.0 was used for data analysis.

\section{Results and Discussion}

\section{Dynamics of soil available micronutrients}

All the micronutrients except B were sufficient in the soil in the experimental site at 4 months (Table 2). There was no significant difference in Mn availability at the 4 month stage. The availability of all micronutrients exhibited an initial increase in almost all the treatments. An increase in micronutrient concentration in soil has been reported (Herencia et al., 2008) with application of organic amendments. Formation of stable complexes by chelation between functional groups of organic compounds and metals blocking their sorption and increase their concentration in soil solution (Madrid, 1999).

Cline et al., (1982) reported that citrate, oxalate, malate, malonate and succinate can all act as chelators of $\mathrm{Fe}, \mathrm{Cu}$ and $\mathrm{Zn}$. Solubility of plant available $\mathrm{Fe}, \mathrm{Mn}, \mathrm{Zn}$ and $\mathrm{Cu}$ increases as soil pH decreases (Brady and Weil, 2002). In addition, application of organic manures increases micronutrient availability in soil (Mahmood et al., 2017). But the status of all micronutrients decreased at harvest except $\mathrm{Zn}$ where temporal variation was meagre. The status of $\mathrm{Cu}$ and $\mathrm{B}$ became deficient after harvest of the crop in all the treatments. Boron sorption to $\mathrm{Fe}$ and $\mathrm{Mn}$ oxide surfaces might have lowered the availability of B in soil (Sarkar et al., 2014). The decrease in the available $\mathrm{Cu}$ may be due to complexation with organic matter (Garrido et al., 2005). The high phosphate content in the soil also decreases mobility of $\mathrm{Cu}$ by chemisorption (KabataPendias and Pendias, 2000). However it was the ROF based treatments that exhibited higher availability of the micronutrients especially at the active growth stage of banana as compared to the FYM based treatments. This point to the efficiency of the ROF based treatments in supplying micronutrients to the crop during the active growth period. Foliar application of micronutrient did not seem to have a significant effect on soil micronutrient availability irrespective of the organic manure source used.

\section{Dynamics of foliar micronutrients}

The accumulation of foliar micronutrients at bunch emergence stage followed the order Fe> $\mathrm{Mn}>\mathrm{Zn}>\mathrm{B}>\mathrm{Cu}$. Souza (2016) also reported a similar order of micronutrient accumulation. Foliar concentration of $\mathrm{Fe}$ and $\mathrm{Zn}$ were higher in STSM compared to OFSTSM (Table 3). High $\mathrm{Fe}$ content was observed to be in coincidence with flag leaf formation in banana. Foliar concentration of $\mathrm{Mn}, \mathrm{Zn}$ and B were also comparatively higher indicating a higher absorption and utilisation at the flowering and fruit setting stages of the banana crop. The effect of $\mathrm{Zn}$ and $\mathrm{B}$ in increasing fruit set and number of fruits have been reported by Saadati et al., (2016). B is instrumental in cell wall formation, differentiation of xylem, a regulatory role in transportation of carbohydrates, nucleic acid synthesis and hormonal responses (Souza, 2016). However the comparatively lower $\mathrm{Cu}$ concentration in the index leaf is suggestive of the enhanced utilisation of $\mathrm{Cu}$ in the vegetative phase rather than at the flowering and fruit setting stages. $\mathrm{Cu}$ is reported to increase the vegetative growth of plants (Kanwal et al., 2016). Although only B was the sole micronutrient needed to be supplemented on soil test basis, the foliar content of all micronutrients remained high. Foliar micronutrient concentration remained high because the soil was inherently having sufficient levels of micronutrients sufficing plant uptake. Raghupathi et al., (2002) reported that majority of $\mathrm{Mn}, \mathrm{Zn}$ and $\mathrm{Cu}$ was found mobilized in leaves. 
Table.1 Treatment combinations of the field experiment

\begin{tabular}{|c|c|c|}
\hline $\begin{array}{l}\text { Treatment } \\
\text { Code }\end{array}$ & Treatments & Dosage \\
\hline $\mathrm{CR}$ & POP (FYM + NPK) & $\mathrm{FYM}_{10 \mathrm{~kg}}+\mathrm{N}_{190 \mathrm{~g}}+\mathrm{P}_{115 \mathrm{~g}}+\mathrm{K}_{300 \mathrm{~g}}$ \\
\hline ST & Modified POP (FYM + STB NPK) & $\mathrm{FYM}_{10 \mathrm{~kg}}+\mathrm{N}_{135 \mathrm{~g}}+\mathrm{P}_{30 \mathrm{~g}}+\mathrm{K}_{75 \mathrm{~g}}+$ Lime $_{100 \mathrm{~g}}$ \\
\hline STSM & $\begin{array}{l}\text { FYM + STB (NPK + Secondary + } \\
\text { Micro) }\end{array}$ & $\begin{array}{l}\mathrm{FYM}_{10 \mathrm{~kg}}+\mathrm{N}_{135 \mathrm{~g}}+\mathrm{P}_{30 \mathrm{~g}}+\mathrm{K}_{75 \mathrm{~g}}+ \\
\mathrm{MgSO}_{450 \mathrm{~g}}+\mathrm{B}_{4 \mathrm{~g}}+\text { Lime }_{100 \mathrm{~g}}\end{array}$ \\
\hline $\operatorname{STSM}(\mathrm{F})$ & $\begin{array}{l}\text { FYM + STB }[N P K+\text { Secondary + } \\
\text { Micro (F)] }\end{array}$ & $\begin{array}{l}\mathrm{FYM}_{10 \mathrm{~kg}}+\mathrm{N}_{135 \mathrm{~g}}+\mathrm{P}_{30 \mathrm{~g}}+\mathrm{K}_{75 \mathrm{~g}}+ \\
\mathrm{MgSO}_{4} 50 \mathrm{~g}+\mathrm{B} 0.2 \%+\text { Lime } \\
100 \mathrm{~g}\end{array}$ \\
\hline FSTSM & $\begin{array}{l}\text { FYM + COF (OF fortified with STB } \\
\text { NPK + Secondary + Micro) }\end{array}$ & $\begin{array}{l}\mathrm{FYM}_{10 \mathrm{~kg}}+\mathrm{COF}_{1 \mathrm{~kg}}+\mathrm{N}_{135 \mathrm{~g}}+\mathrm{P}_{30 \mathrm{~g}}+\mathrm{K} \\
75 \mathrm{~g}+\mathrm{MgSO}_{450 \mathrm{~g}}+\mathrm{B}_{4 \mathrm{~g}}+\text { Lime }_{100 \mathrm{~g}}\end{array}$ \\
\hline $\operatorname{FSTSM}(\mathrm{F})$ & $\begin{array}{l}\text { FYM + COF }[\text { OF fortified with STB } \\
\text { NPK + Secondary + Micro(F)] }\end{array}$ & $\begin{array}{l}\mathrm{FYM}_{10 \mathrm{~kg}}+\mathrm{COF}_{1 \mathrm{~kg}}+\mathrm{N}_{135 \mathrm{~g}}+\mathrm{P}_{30 \mathrm{~g}}+ \\
\mathrm{K}_{75 \mathrm{~g}}+\mathrm{MgSO}_{450 \mathrm{~g}}+\mathrm{B} 0.2 \%+\mathrm{Lime}_{100 \mathrm{~g}}\end{array}$ \\
\hline FSTSMP & $\begin{array}{l}\text { FYM + COF (OF fortified with STB } \\
\text { NPK + Secondary + Micro) + PGPR } \\
\text { Mix I }\end{array}$ & $\begin{array}{l}\mathrm{FYM}_{10 \mathrm{~kg}}+\mathrm{COF}_{1 \mathrm{~kg}}+\mathrm{N}_{135 \mathrm{~g}}+\mathrm{P}_{30 \mathrm{~g}}+ \\
\mathrm{K}_{75 \mathrm{~g}}+\mathrm{MgSO}_{450 \mathrm{~g}}+\mathrm{B}_{4 \mathrm{~g}}+\mathrm{PGPR}_{\mathrm{Pix}} \mathrm{I} \\
2 \%+\mathrm{Lime}_{100 \mathrm{~g}}\end{array}$ \\
\hline OFSTSM & $\begin{array}{l}\text { COF (basal) + COF (OF fortified } \\
\text { with STB NPK + Secondary + } \\
\text { Micro) }\end{array}$ & $\begin{array}{l}\mathrm{COF}_{2 \mathrm{~kg}}+\mathrm{N}_{135 \mathrm{~g}}+\mathrm{P}_{30 \mathrm{~g}}+\mathrm{K}_{75 \mathrm{~g}}+\mathrm{MgSO}_{4} \\
50 \mathrm{~g}+\mathrm{B}_{4 \mathrm{~g}}+\text { Lime }_{100 \mathrm{~g}}\end{array}$ \\
\hline
\end{tabular}

POP: Package of practices, FYM: Farm yard manure, STB: Soil test based, Micro: Micronutrients, COF: Customised organic fertilizer, (F): Foliar application; PGPR was mixed with FYM @ 2\%

Table. 2 Changes in soil available micronutrients at the active growth and harvest stages of banana

\begin{tabular}{|c|c|c|c|c|c|c|c|c|c|c|}
\hline \multirow[t]{3}{*}{ Treatments } & \multicolumn{5}{|c|}{ At 4 months } & \multicolumn{5}{|c|}{ At harvest stage } \\
\hline & $\mathrm{Fe}$ & $\mathrm{Mn}$ & $\mathrm{Zn}$ & $\mathrm{Cu}$ & B & $\mathrm{Fe}$ & $\mathrm{Mn}$ & $\mathrm{Zn}$ & $\mathrm{Cu}$ & B \\
\hline & \multicolumn{5}{|c|}{$\mathrm{mg} \mathrm{kg}^{-1}$} & \multicolumn{5}{|c|}{$\mathrm{mg} \mathrm{kg}^{-1}$} \\
\hline $\mathbf{C R}$ & $332.25^{d}$ & 19.20 & $2.71^{g}$ & $2.5^{\mathrm{bc}}$ & $0.07^{\mathrm{c}}$ & $121.5^{c}$ & $14.70^{\mathrm{a}}$ & $7.04^{b}$ & 0.7 & $0.09^{\mathrm{b}}$ \\
\hline ST & $321.25^{\mathrm{e}}$ & 15.91 & $3.43^{\mathrm{e}}$ & $1.9^{\mathrm{c}}$ & $0.09^{\mathrm{c}}$ & $54.53^{f}$ & $7.13^{c}$ & $6.20^{\mathrm{e}}$ & 0.3 & $0.11^{\mathrm{a}}$ \\
\hline STSM & $331.75^{d}$ & 12.91 & $5.18^{\mathrm{a}}$ & $3.9^{a}$ & $0.19^{\mathrm{a}}$ & $66.85^{\mathrm{e}}$ & $9.15^{\mathrm{bc}}$ & $4.51^{\mathrm{g}}$ & 0.6 & $0.08^{b c}$ \\
\hline$\overline{\operatorname{STSM}(\mathbf{F})}$ & $360.5^{c}$ & 18.97 & $4.80^{\mathrm{b}}$ & $3.8^{\mathrm{a}}$ & $0.14^{\mathrm{b}}$ & $116.91^{\mathrm{c}}$ & $11.53^{\mathrm{ab}}$ & $7.46^{\mathrm{a}}$ & 1.1 & $0.07^{\mathrm{bc}}$ \\
\hline FSTSM & $388.75^{b}$ & 19.20 & $3.81^{\mathrm{d}}$ & $3.5^{\mathrm{ab}}$ & $0.15^{b}$ & $74.90^{\mathrm{d}}$ & $14.70^{\mathrm{a}}$ & $3.75^{h}$ & 0.7 & $0.07^{\text {bc }}$ \\
\hline$\overline{\text { FSTSM (F) }}$ & $407.25^{a}$ & 15.42 & $4.27^{c}$ & $3.8^{\mathrm{a}}$ & $0.16^{b}$ & $82.87^{\mathrm{d}}$ & $7.44^{b c}$ & $5.89^{\mathrm{f}}$ & 0.9 & $0.06^{b c}$ \\
\hline FSTSMP & $401.75^{a}$ & 15.01 & $2.89^{\mathrm{f}}$ & $3.0^{\mathrm{abc}}$ & $0.17^{\mathrm{ab}}$ & $169.48^{a}$ & $10.81^{\mathrm{abc}}$ & $6.81^{\mathrm{c}}$ & 0.6 & $0.05^{c}$ \\
\hline OFSTSM & $306.25^{f}$ & 13.76 & $5.29^{\mathrm{a}}$ & $3.1^{\mathrm{abc}}$ & $0.14^{\mathrm{b}}$ & $136.93^{b}$ & $7.92^{b c}$ & $6.43^{d}$ & 0.5 & $0.08^{b}$ \\
\hline $\operatorname{SEm}( \pm)$ & 4.165 & 3.373 & 0.069 & 0.541 & 0.014 & 3.731 & 1.919 & 0.054 & 0.292 & 0.012 \\
\hline CD (0.05) & 8.934 & NS & 0.148 & 1.161 & 0.029 & 8.002 & 4.116 & 0.115 & NS & 0.025 \\
\hline
\end{tabular}


Table.3 Foliar micronutrient concentration of banana as affected by farmyard manure based and rapid organic fertilizer based treatments

\begin{tabular}{|c|c|c|c|c|c|}
\hline \multirow[t]{2}{*}{ Treatments } & \multicolumn{5}{|c|}{ Foliar micronutrient concentration (at bunch emergence) } \\
\hline & $\begin{array}{l}\mathrm{Fe} \\
\left(\mathrm{mg} \mathrm{kg}^{-1}\right)\end{array}$ & $\begin{array}{l}\mathrm{Mn} \\
\left(\mathrm{mg} \mathrm{kg}^{-1}\right)\end{array}$ & $\begin{array}{l}\mathrm{Zn} \\
\left(\mathrm{mg} \mathrm{kg}^{-1}\right)\end{array}$ & $\begin{array}{l}\mathrm{Cu} \\
\left(\mathrm{mg} \mathrm{kg}^{-1}\right)\end{array}$ & $\begin{array}{l}\text { B } \\
\left(\mathrm{mg} \mathrm{kg}^{-1}\right)\end{array}$ \\
\hline $\mathbf{C R}$ & $334.09^{\mathrm{g}}$ & $404.18^{b}$ & $17.0^{\mathrm{b}}$ & $3.0^{\mathrm{bc}}$ & $23.91^{\text {bcd }}$ \\
\hline ST & $395.14^{\mathrm{g}}$ & $168.32^{\mathrm{de}}$ & $15.5^{b}$ & $5.0^{b}$ & $18.04^{\mathrm{d}}$ \\
\hline STSM & $1043.23^{c}$ & $104.47^{\mathrm{f}}$ & $17.0^{\mathrm{b}}$ & $5.0^{b}$ & $24.35^{\mathrm{abc}}$ \\
\hline STSM(F) & $793.11^{d}$ & $121.24^{\mathrm{ef}}$ & $13.5^{\mathrm{bc}}$ & $3.5^{\mathrm{bc}}$ & $29.78^{a b}$ \\
\hline FSTSM & $2047.31^{\mathrm{a}}$ & $254.17^{c}$ & $22.5^{\mathrm{a}}$ & $2.5^{\mathrm{bc}}$ & $23.04^{\mathrm{cd}}$ \\
\hline FSTSM (F) & $1177.29^{b}$ & $405.16^{b}$ & $16.5^{b}$ & $10.0^{\mathrm{a}}$ & $21.52^{\mathrm{cd}}$ \\
\hline FSTSMP & $615.18^{e}$ & $470.29^{a}$ & $10.0^{c}$ & $0.5^{c}$ & $26.30^{a b c}$ \\
\hline OFSTSM & $503.08^{f}$ & $195.12^{\mathrm{cd}}$ & $13.5^{\mathrm{bc}}$ & $1.5^{b c}$ & $30.00^{\mathrm{a}}$ \\
\hline $\operatorname{SEm}( \pm)$ & 45.419 & 29.532 & 1.704 & 1.712 & 2.838 \\
\hline CD (0.05) & 97.424 & 63.347 & 3.656 & 3.673 & 6.087 \\
\hline
\end{tabular}

Table.4 Bunch yield and bunch characters of banana as affected by micronutrients in farmyard manure and rapid organic fertilizer based treatments

\begin{tabular}{|l|l|l|l|l|}
\hline Treatments & $\begin{array}{l}\text { Bunch weight } \\
\text { plant }\end{array}$ & $\begin{array}{l}\text { Number of hands } \\
\text { bunch }\end{array}$ & $\begin{array}{l}\text { Number of fingers } \\
\text { bunch }\end{array}$ & $\begin{array}{l}\text { Length of peduncle } \\
(\mathrm{cm})\end{array}$ \\
\hline CR & $8.50^{\mathrm{b}}$ & $5.11^{\mathrm{ab}}$ & $46.33^{\mathrm{ab}}$ & $41.82^{\mathrm{bc}}$ \\
\hline ST & $9.66^{\mathrm{ab}}$ & $4.98^{\mathrm{abc}}$ & $41.22^{\mathrm{cd}}$ & $41.14^{\mathrm{c}}$ \\
\hline STSM & $10.74^{\mathrm{a}}$ & $5.38^{\mathrm{ab}}$ & $46.75^{\mathrm{a}}$ & $44.14^{\mathrm{a}}$ \\
\hline STSM(F) & $8.19^{\mathrm{b}}$ & $5.22^{\mathrm{ab}}$ & $43.28^{\mathrm{bcd}}$ & $41.40^{\mathrm{c}}$ \\
\hline FSTSM & $9.29^{\mathrm{ab}}$ & $4.95^{\mathrm{abc}}$ & $43.20^{\mathrm{bcd}}$ & $40.72^{\mathrm{c}}$ \\
\hline FSTSM (F) & $7.80^{\mathrm{b}}$ & $4.52^{\mathrm{c}}$ & $40.06^{\mathrm{d}}$ & $38.44^{\mathrm{d}}$ \\
\hline FSTSMP & $8.38^{\mathrm{b}}$ & $4.87^{\mathrm{bc}}$ & $43.20^{\mathrm{bcd}}$ & $41.53^{\mathrm{bc}}$ \\
\hline OFSTSM & $10.67^{\mathrm{a}}$ & $5.51^{\mathrm{a}}$ & $44.32^{\mathrm{abc}}$ & $43.35^{\mathrm{ab}}$ \\
\hline SEm( \pm ) & 0.924 & 0.264 & 1.515 & 0.895 \\
\hline CD (0.05) & 1.983 & 0.566 & 3.250 & 1.919 \\
\hline
\end{tabular}


Fig.1 Total dry matter production of banana as influenced by micronutrients in farmyard manure and rapid organic fertilizer based treatments. Error bars indicate standard deviation from the means of three replicates

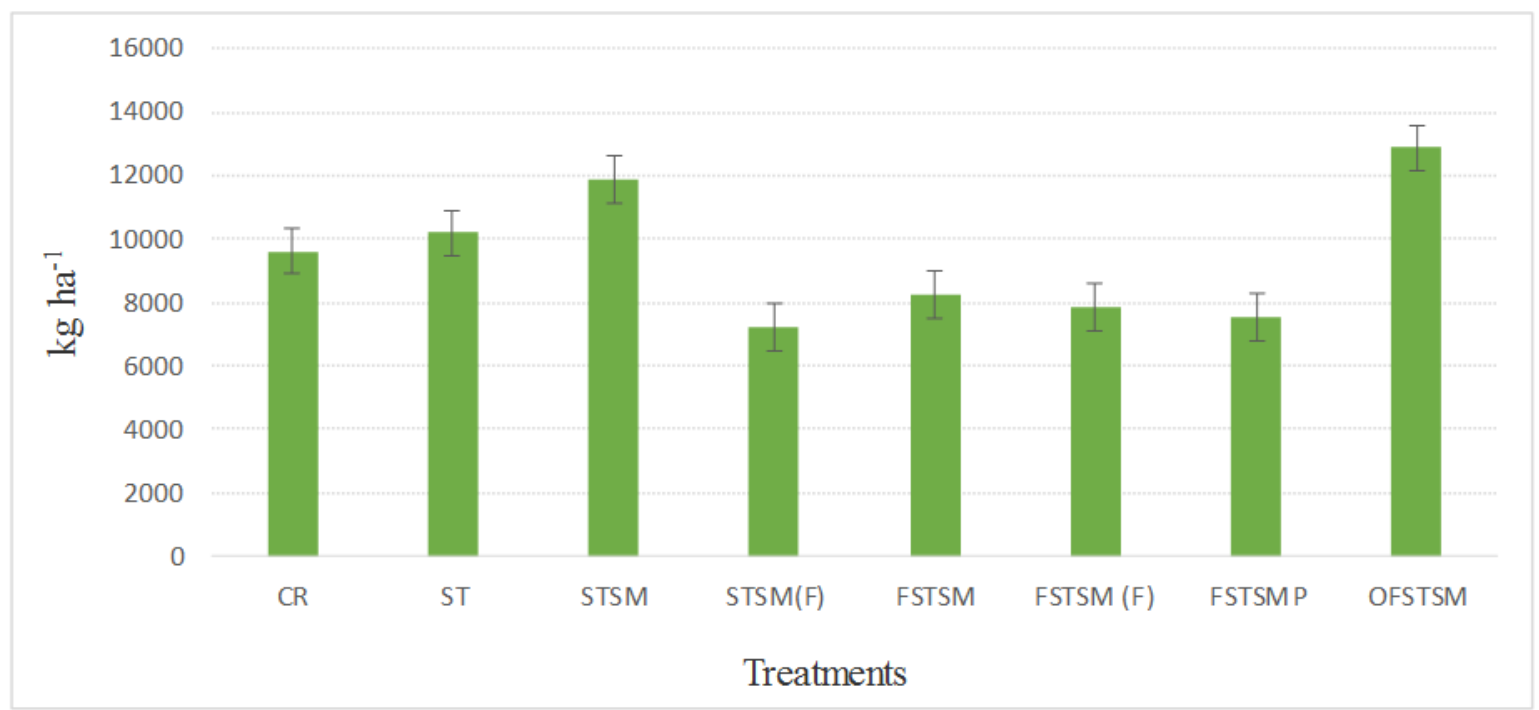

Moreover, the farmyard manure and rapid organic fertilizer contained all the micronutrients in quantities sufficient for plant growth. Hence no difference was apparent in foliar concentration of micronutrients due to the difference in their sources. As far as the mode of micronutrient application is concerned too, a significant superiority in foliar applied treatments could not be observed, irrespective of being FYM based or ROF based.

\section{Bunch yield and bunch characters}

The yield and important yield characters subjected to study reflected the superiority of the FSTSM and OFSTSM treatments. The highest bunch yield of $10.74 \mathrm{~kg}$ was recorded by FSTSM treatment which was on par with the $10.67 \mathrm{~kg}$ bunch yield of OFSTSM (Table 4). The bunch yield realised was in the order STSM > OFSTSM >ST > FSTSM >CR> FSTSMP > STSM (F) >FSTSM (F). Micronutrient application had a significant influence on bunch yield as seen in the treatments STSM and OFSTSM as compared to $\mathrm{CR}$ and ST. Micronutrients $\mathrm{Fe}, \mathrm{Mn}$ and $\mathrm{Cu}$ are essential for photosynthesis, oxidationreduction reactions, electron transport, chlorophyll synthesis, synthesis and activation of various enzymes etc. The effect of micronutrients on enhancing various metabolic processes influencing higher yield had been reported by many workers (Borges and Caldes, 2004; Mahouachi, 2007). The number of hands per bunch was highest (5.51) in OFSTSM treatment which was on par with the FYM based treatments. STSM treatment registered highest number of fingers per bunch which was on par with $\mathrm{CR}$ and OFSTSM treatments. Highest length of peduncle $(44.14 \mathrm{~cm})$ was noted in STSM treatment which was on par with the OFSTSM treatment.

\section{Total dry matter production}

The highest dry matter production of 12868.21 $\mathrm{kgha}^{-1}$ was recorded in the OFSTSM treatment which was on par with the STSM treatment (Fig. 1). Total dry matter production in the eight treatments followed 
the order OFSTSM >STSM $>$ ST $>$ CR> FSTSM (F) > FSTSMP > FSTSM > STSM (F). Micronutrients play a vital role of in contributing to the dry matter production and enhancing the productivity of banana. Turner and Barkus (1980) observed that Mn concentration in fruit dry matter was directly proportional to the Mn supply. OFSTSM, the rapid organic fertilizer treatment with soil test based micronutrients contributed to the highest total dry matter production conforming its superiority over farmyard manure based and combination treatments.

The organic fertilizer produced by rapid thermochemical processing is capable of a steady supply of plant available micronutrients in soil over the conventional farmyard manure based fertilizers. The equivalence in foliar nutrient concentration suggests that the rapid organic fertilizer is as effective as the conventional farmyard manure. Direct foliar application of micronutrients was not advantageous over soil application in conjunction with other nutrients, irrespective of the organic manure source, thus reducing the cost of production. Soil test based micronutrient application is indispensable for realising higher crop productivity in banana in terms of bunch weight and total dry matter production, without having prejudice to the type of organic fertilizer applied. As far as the micronutrient dynamics in the soil-plant system is concerned, the rapid organic fertilizer produced from degradable waste through thermochemical processing proved to be a substitute for farmyard manure.

\section{References}

Borges, A.L., and Caldas, R.C. 2004. Nutrient levels in banana leaves, cultivar Pacovan, grown under irrigation. Agrotecnologia, 28(5): 1099-1106.

Brady, N.C., and Weil, R.R. 2002. The nature and properties of soils, 13th Ed. Prentice Hall Inc., New Jersey, USA. 960p.

Cline, G. R., Powell, P. E., Szanislo, P. J. and Reid, C. P. P. 1982. Comparison of the abilities of hydroxamic, synthetic and other natural organic acids to chelate iron and other ions in nutrient solution. Soil Sci. Soc. Am. J. 46: 1158-1164.

Das, D.K. 2003. Micronutrients: Their behaviors in soils and plants. Kalyani Publications, Ludhiana.

Fawzy, Z.F., El-Bassiony, A.M. and Neama, M.M. 2016. Comparison of nitrogen fertilizer sources and rates on growth and productivity of squash plants. Int. J. Pharm. Tech. Res. 9(8): 51-57.

Garrido, F., Illera, V., Garcia-Gonzalez, M.T. 2005. Effect of the addition of gypsumand lime-rich industrial by-products on $\mathrm{Cd}, \mathrm{Cu}$ and $\mathrm{Pb}$ availability and leachability in metal-spiked acid soils. Appl. Geochem. 20 (2): 397-408.

Herencia, J.F., Ruiz, J.C., Morillo, E., Melero, S., Villaverde, J. and Maqueda, C. 2008. The effect of organic and mineral fertilization on micronutrient availability in soil. Soil Sci. 173(1): 6980.

Kabata-Pendias, A., and Pendias, H. 2000. Trace Elements is Soils and Plants. CRC Press, Boca Raton, Florida, USA.

Kanwal, N., Hanif, M.A., Khan, M.M., Ansari, T.M. and Khalil-ur-Rehman. 2016. Effect of micronutrients on vegetative growth and essential oil contents of Ocimum sanctum. J. Essential Oil Bearing Plants 19(4): 980988.

Leno, N., Sudharmaidevi, C.R. and Meera, A.V. 2016. Fertility evaluation and manurial effect of organic manure produced from degradable solid waste by rapid conversion technology. Adv. Life Sci. 5(11): 4433-4436.

Lyngdoh, C., Bahadur, V., David, A.A., 
Prasad, V.M. and Jamir, T. 2017. Effect of Organic Manures, Organic Supplements and Biofertilizers on Growth and Yield of Cowpea [Vigna unguiculata (L.) Walp]. Int. J. Curr. Microbiol. App. Sci. 6(8):1029-1036.

Madrid, L. 1999. Metal retention and mobility as influenced by some organic residues added to soils: A case study. In: (Eds.) Selim, H. M. and Iskandar, I. K. Fate and Transport of Heavy Metals in the Vadose Zone. Lewis Publishers, Boca Raton, pp. 201-223.

Mahmood, F., Khan, I., Ashraf, U., Shahzad, T., Hussain, S., Shahid, M., Abid, M. and Ullah, S. 2017.Effects of organic and inorganic manures on maize and their residual impact on soil physicochemical properties. J. Soil Sci.PlantNutr.

Mahouachi, J. 2007. Growth and mineral nutrient content of developing fruit on banana plants (Musa acuminate AAA, 'Grand Nain') subjected to water stress and recovery. J. Hort. Sci. Biotechnol. 82(6): 839-844.

Marschner, H. 1995. Mineral nutrition of higher plants. Academic Press, San Diego.

Mohapatra, D., Mishra, S. and Sutar, N. 2010. Banana and its by-product utilisation: an overview. J. Sci. Ind. Res. 69:323329.

Raghupathi, H.B., Reddy, B.M.C. and Srinivas, K. 2002. Multivariate diagnosis of nutrient imbalance in banana. Commun. Soil Sci. Plant Anal.
33: 2131-2143.

Saadati, S., Moallemi, N., Mortazavi, S.M.H. and Seyyednejad, S.M. 2016.Foliar applications of zinc and boron on fruit set and some fruit quality of olive. Crop Res51:1-8.

Sarkar, D., De, D.K., Das, R. and Mandal, B. 2014. Removal of organic matter and oxides of iron and manganese from soil influences boron adsorption in soil. Geoderma, 213-216.

Shalini, V.P.S., and Jangid, B., 2017. Yield and economics in direct seeded rice using organic manures and micronutrients. Int. J. Chem Stud. 5(3): 105-109.

Souza, B.P.D., Silva, E.D.B., Cruz, M., Do Céu, M.D., Amorim, E.P. and Donato, S.L.R. 2016. Micronutrients Deficiency on the Nutritional Status of Banana Prata Seedlings. Revista Brasileira de Fruticultura 38(3): e-884. [http://www.scielo.br/pdf/rbf/v38n3/010 0-2945-rbf-38-3-e-884.pdf].

Sudharmaidevi, C.R., Thampatti, K.C.M. and Saifudeen, N. 2017. Rapid production of organic fertilizer from degradable waste by thermochemical processing. Int. J. Recycling Organic Waste Agric. 6: 1-11.

Turner, D.W., and Barkus, B. 1980. Plant growth and dry-matter production of the 'Williams' banana in relation to supply of potassium, magnesium and manganese in sand culture. Scientia Horticulturae 12(1): 27-45.

\section{How to cite this article:}

Naveen Leno and Sudharmaidevi, C.R. 2018. Micronutrient Dynamics on Addition of a Rapid Organic Fertilizer Produced from Degradable Waste in Banana. Int.J.Curr.Microbiol.App.Sci. 7(01): 1095-1102. doi: https://doi.org/10.20546/ijcmas.2018.701.132 